\title{
Interethnic Antagonism in the Wake of Colonialism: U.S. Territorial Racial and Ethnic Relations at The Margins
}

\author{
Michael P. Perez 1 \\ California State University, Fullerton
}

Since the proliferation of scholarship on racial and ethnic antagonism following the Civil Rights era, neoMarxist, colonialism, and other power-conflict theories reached popularity and have been widely applied to explain racial and ethnic conflict throughout the world, particularly in the United States. However there is a lack of scholarship on racial and ethnic relations in the U.S. territories in general and the Pacific Islands in particular. Although a few works exist in terms of interethnic antagonism and anti-immigrant sentiment in Puerto Rico, Melanesia, and Hawaii, there is a lack of research on interethnic antagonism in Micronesia; therefore comparative analyses of race and ethnicity in the context of U.S. territorial relations would contribute to the general body of knowledge in ethnic studies. In light of Micronesia's complex colonial history and its contemporary political and economic context (i.e. immigration, labor exploitation, territorial relations, neocolonialism, indigenous sovereignty struggles, and garment, tourist, and construction industries), understanding of intergroup relations in Micronesia would also benefit from an analysis of interethnic antagonism. 
As a territory of the United States the island of Guam is particularly situated within the eye of this political economic storm. Indeed Guam is the industrial center of Micronesia and a popular destination for capital, industries, the military, tourists, migrants, and labor. Compounding antagonistic racial, ethnic, and indigenous relations surrounding self-determination, sovereignty, military, and political status issues, Guam's colonial history is marked by political subjugation, military land acquisition, lopsided economic development, colonial immigration policy, and tremendous inmigration. In particular given the lack of local control of Guam's economy and in-migration, these remain central issues surrounding intergroup conflict on the island. Yet how are these dynamics played out within a territorial possession whereby diverse cultures and political economic interests converge in the wake of colonialism?

In this paper, I offer an interpretive note on interethnic antagonism between the Chamorro population (indigenous people of the Mariana Islands) and nonChamorros, particularly labor migrant groups in Guam. In doing so, I construct a theoretical model of interethnic antagonism derived from diverse perspectives (i.e. colonial, split labor market, middleman minority, cultural, and postcolonial studies) and critically analyze the political economic history of Guam.

\section{Introduction}

Intergroup conflict is an inextricable feature of diverse stratified societies. A heterogeneity of cultural, religious, historical, political, and economic interests lay the foundation for interethnic antagonism. The diverse complexion of the United States is an instructive case in point, whereby racial and ethnic conflict have marked intergroup relations from the discovery of the New World to the 1992 Los Angeles uprising. Many perspectives on intergroup conflict exist that range across psychological, cultural, and social explanations. Considering the capitalist and colonial contexts of intergroup relations, funda- 
mental social sources of intergroup conflict are apparent (i.e. labor exploitation, divide and conquer maneuvers, splitting the labor market). In turn there has been a proliferation of scholarship on interethnic antagonism in the United States establishing a paradigm of ethnic studies scholarship beyond conventional assimilationist and biracial theorizing. ${ }^{2}$ However,there is a lack of scholarship on interethnic relations in the U.S. territories in general and the Pacific Islands in particular. Although a few works on interethnic antagonism and anti-immigrant sentiment in Puerto Rico, Melanesia, and Hawaii exist, there is a lack of research on interethnic antagonism in Micronesia. ${ }^{3}$ Therefore comparative analyses of interethnic relations in the context of U.S. territorial relations would contribute to the general body of ethnic studies knowledge.

Because of Micronesia's diversity, complex colonial history and contemporary political economic context, conflict is a common feature of intergroup relations there. As a territory of the United States the island of Guam is situated particularly within the eye of this political economic storm. Guam is the industrial hub of Micronesia and a popular destination for capital, industries, military, tourists, labor, and migrants simply searching for a better life. Compounding antagonistic racial, ethnic, and indigenous relations surrounding self-determination, sovereignty, military, and political status issues, Guam's colonial history is marked by political subjugation, military land acquisition, lopsided economic development, colonial immigration policy, and tremendous in-migration. Guam represents an interesting context of analysis of interethnic antagonism given its state of being remote controlled by the United States. In particular given the lack of local control over in-migration, these remain central issues and sources of intergroup conflict between Chamorros and non-Chamorros. For instance, Chamorro-Filipino relations have historically involved conflict. Vicente M. Diaz describes the annual celebration of Chamorro heritage in Guam - Chamorro Week:

...in the 1970s, Chamorro Week in the public school system was as much an occasion-however ghettoized-to express pride in one's Chamorro heritage as it was an open season to beat up individuals labeled 


\section{Ethnic Studies Review Volume 23}

"Tagaloos"....Filipinos, on the other hand, are not innocent bystanders, poor helpless immigrants, who want only to live a life of dignity often denied back home. Many Filipinos look down on Chamorros as not as culturally rich as people in their mother country. ${ }^{4}$

In recent years there have been incidents of conflict, at times violent, between Chamorros and other non-Chamorros. Yet how do these dynamics play out within a territorial possession where diverse cultures and economic and political interests converge in the wake of colonialism?

For clarification Chamorros are the indigenous people of the Mariana Islands while Guam is the largest and Southernmost of the Marianas chain in Micronesia of the Western Pacific. Contemporary Chamorros are descendants of precontact inhabitants referred to as Ancient Chamorros, who settled the islands over 3,000 years ago. 5 With the dramatic decline of the ancient Chamorro population due to colonialism, annihilation, and disease, the Spanish census began classifying Chamorros into a hybrid neo-Chamorro racial mixture in the late 1900s.6 Thus contemporary Chamorros are technically linked to this neo-Chamorro mixture, which culturally combines indigenous, Spanish, Mexican, and Filipino influences. Nonetheless Chamorros remain true to their roots as expressed in their ongoing cultural resilience and trace their origin to the precontact era. ${ }^{7}$

Given the influx of non-Chamorro groups through the years, Guam evolved into a diverse society. Based on the 1990 census of Guam, there were 133,152 residents made up of $38 \%$ Chamorros, 23\% Filipinos, $21 \%$ other Asians and Pacific Islanders, and 14\% Caucasians. ${ }^{8}$ Other than Filipinos the largest Asian group was Korean, followed by Japanese and Chinese respectively. Palauans and Chuukese made up the largest Pacific Islander groups from Micronesia other than Chamorros. 9

In this paper I explore interethnic antagonism between Chamorros and non-Chamorros in the context of colonialism in Guam. I offer an interpretive theoretical note by drawing on diverse perspectives to critically analyze the political economic history of interethnic relations in Guam. In doing so this paper 
provides an overview of Guam's political history, constructs an integrated theoretical model of interethnic antagonism, and historically analyzes interethnic antagonism in Guam drawing from the theoretical framework and literature.

\section{An Overview of Guam's Political History}

Interethnic conflict in Guam is inherently rooted in a complex political history. It is therefore important to clarify this political historical context. Since my focus is on interethnic antagonism in the context of capitalism and U. S. colonialism, I refer exclusively to Guam's political history following U.S. capture from Spain in 1898. I particularly discuss the beginning of the American era in Guam, Japanese Occupation/Guam Liberation, citizenship-decolonization, and U.S. neocolonialism.

\section{Beginning of the American Legacy and U.S. Territorial Relations in Guam}

Sparked by North American imperialism, the late 1800s marked the beginning of United States' occupation of Guam. As the geopolitical arena became more complex and globalized during this era, the U.S. especially became interested in expanding its military presence in the Pacific Islands, Asia, and the Caribbean. Likewise Guam was intimately tied to U.S. intentions to establish authority in the Philippines thereby becoming the most strategic U.S. colonial outpost in the Pacific. Also as the Spanish-American War was in motion, the U.S. was interested in occupying Spain's colonies in these areas. ${ }^{10}$

Through a series of political mandates by the U.S. Guam came under the military control of the United States for its strategic location in the Pacific Rim and was officially annexed via the Treaty of Paris on December 10, 1898.11 In addition to the establishment of a military institution, the United States transplanted other American social institutions (i.e. polity, law, and education). Guam eventually became an extension of the American normative structure, subjugating Chamorros to American social standards which profoundly affected Chamorro self-concept.12 Sovereign authority of Guam was placed in the hands of the United States and was to remain 
there for years to come with the exception of the Japanese Occupation during World War II.

Treaty negotiations between the U.S., Spain, and the international community set the stage for legitimate and paternalistic control of Chamorros in Guam. ${ }^{13}$ As control of Guam emerged out of the context of military interests, the Navy politically subjugated Chamorros for military interests. For instance naval administration in the late 1800 s limited various local practices and activities through civil mandates. ${ }^{14}$

The legitimacy of U.S. authority on Guam was sealed in 1901 with the U.S. Supreme Court decision in the Insular Cases. A major issue surrounding these cases was "whether constitutional restrictions (such as the Tenth amendment) on congressional authority over the U.S. states also served to check federal power over the new island acquisitions." 15 In the case of Downes v. Bidwell the Supreme Court ruled that "insular territories" were not equivalent to the states; thus the U.S. Congress had unlimited authority over its territories since the Constitution of the United States was inapplicable. The political status of Guam remained obscure thus enabling unprecedented subjugation of Chamorros by the Navy and Congress during the early 1900 s.

\section{Japanese Occupation and Guam Liberation}

World War II placed Guam in a precarious situation. The Japanese occupied Guam during 1941 and 1944 as a result of shortcomings on the part the U.S. to secure a sufficient military fortress and dominance in the Pacific. When Guam was "liberated" by the U.S. on July 21,1944 , the U.S. reestablished its authority on Guam. To prevent future military vulnerabilities the U.S. initiated an aggressive campaign to institute political and military dominance. Guam, thereby, was recognized for its strategic geopolitical value in a new light. Due to being "rescued" by the U.S. from Japanese occupation, the majority of Chamorros became highly patriotic and grateful for American rule in the 1940s as an extension of their appreciation with the generosity and reciprocity so characteristic of their indigenous culture. 16

The reality of American "rescue" became painfully obvious with the lack of concern for postwar civilian conditions ${ }^{17}$. The 
years following the War were again marked by political subjugation that boiled into discontent among Chamorros and escalated the political contestation of the 1950s and 1960s. For instance the fact later surfaced that Chamorros were not consulted as the United States waived Chamorro war claims against the Japanese as part of peace treaty negotiations. Furthermore numerous Chamorros who had been placed in refugee camps were not allowed to resettle on their lands and remained in unstable settings for nearly two years following Liberation. ${ }^{18}$ Some Chamorros were never permitted to move back to their land. The U.S. Government further seized land in the interest of national defense. Displacement of Chamorros from the land profoundly affected Chamorro identity. Rooted in ancient Chamorro society, land continues to be central to indigenous culture, for at one time Guam was seen as "a sacred place to the Ancient Chamorros who believed that all life Sprang from its soil." 19 In the beginning of World War II the U.S. had acquired over one-third of the island. With revitalized post-World War II military interests in developing Guam into a military fortress, the U.S. claimed huge pieces of land with the goal of possessing over half of the island.20

Likewise Guam's economy was subordinate to military interests and thus was underdeveloped. Although Guam experienced some economic progress following the War as a result of U.S. economic prosperity and military expansion, U.S. military policy in Guam was specifically aimed at restricting free enterprise for security reasons and to prevent labor exploitation. ${ }^{21}$ Ironically, the U.S. military exploited labor as well as land.

The United States presence in Guam was also aimed at promoting acculturation, with education as a major vehicle of Americanization. ${ }^{22}$ Compulsory public education that was immediately established following U.S. annexation in the late 1800s was intended to establish English as the official Ianguage replacing the Chamorro and Spanish languages. In addition to language other dimensions of cultural behavior were constrained. For instance local customs and celebrations were replaced with federal holidays through mandates requiring observance. As the process of Americanization escalated following Liberation, many Chamorros became highly mal- 


\section{Ethnic Studies Review Volume 23}

leable and patriotic toward the United States to the point of feeling forever in debt to "America." 23

\section{Drive for Citizenship and Decolonization}

In light of the rapid changes brought on by Americanization Chamorros began a quest for U.S. citizenship and civilian government. ${ }^{24}$ Various petitions for self-government and citizenship were filed in Washington over the years. What were initially docile efforts toward U.S. citizenship in the 1920s escalated. Chamorro leaders went to Washington to lobby and communicate Chamorro grievances and their desire for citizenship. ${ }^{25}$

Other political developments fueled the Chamorro drive for citizenship and decolonization. With the emergence of New World politics after World War II, the promise of self-determination was articulated with the creation of an oversight council-the U.N. Trusteeship Council.26 Additionally the Guam Congress was established and granted authority to legislate.

In 1945 land claims became a focal issue of political protest as Chamorro land rights were obscured and continued to be violated for military interests. Years of festering animosity towards subjugation by the military government converged at a heated confrontation between the Guam Congress and Governor Pownall in 1949, thereby culminating in the removal of naval government from Guam. President Truman formally transferred administrative control of Guam from the Navy to the Department of the Interior and appointed the first civilian governor of Guam, Carlton S. Skinner. ${ }^{27}$ Civilian election of the governor eventually replaced executive appointment further empowering the people of Guam.

Following years of enduring political opposition the Chamorro drive for U.S. citizenship and to limited military control was codified with the Organic Act of Guam. The 1950 Organic Act led to a number of steps toward self-rule and decolonization. With the local government being placed in civilian hands, three conventional branches of democratic governance were established along with a Bill of Rights. In 1951 the Guam Congress was replaced by the First Guam Legislature which enabled further local political control. Finally Chamorros could travel more freely to the U.S. mainland. 


\section{U.S. Neocolonialism}

Despite landmark social and political changes surrounding the Organic Act, Guam's strategic value remained a primary concern to the U.S. Neocolonialism surfaced in subtle forms but with the same intention to remote control Guam and its people. This is related to the fact that Chamorros did not vote on the Organic Act yet are governed within its parameters. Although Chamorros obtained American citizenship, thereby transforming Guam from an "unorganized" territory to an "organized" territory, their newly acquired citizenship status remains second-class. The U.S. government in many ways continued to treat Guam as an unorganized U.S. possession under the rationale of the Insular Cases. As a result of being granted congressional versus constitutional U.S. citizenship, the Chamorros did not acquire many conventional constitutional rights of U.S. citizenship. They were denied full protection from federal and congressional authority, participation in national politics; federal, social, and economic benefits; and constitutional protection under the American legal system. 28

Despite enduring efforts toward self-determination, the replacement of military government with civilian government, and transfer of authority from the Navy to the Department of the Interior, the Organic Act conferred limited self-government to the people of Guam with significant power remaining in military hands. Ironically the immediate tone of the Organic Act seemed to limit self-rule. The neocolonial intentions of the U.S. were confirmed at the onset as Guam was declared an "unincorporated" versus "incorporated" territory indicating a lack of intention to incorporate Guam in union with the U.S. as a state.29 The U.S. Congress maintained full authority to legislate and even amend the Organic Act without consent of the local people. The President of the United States also maintained authority to claim any portion of Guam's land for military purposes. In the meantime the military continued to control over $36 \%$ of the island. 30

In addition, although a unicameral legislature comprised of many local leaders was well established, the traditional balance of power characteristic of the states was not the case on Guam. In actuality Guam's executive pranch ranked above the legislative branch, thus limiting the voice of the people. 
Although the formal goal of the Interior was to transcend the colonial aftermath of Guam, decolonization efforts were either lost within the complex bureaucracy of the Interior or remained a low priority in Washington D.C. In short the people of Guam were granted the label of American citizenship and self-government yet still lacked a fully legitimate voice. This set the tone for a new era of political subjugation.

With a new tide of geopolitical interests and developments combined with Guam's obscure status subsequent instances of political subjugation surfaced. International political relations in the mid-1900s revitalized military interests in Guam. For instance anticommunist sentiment, the Cold War, and the Vietnam War plunged Guam into a new chapter of national defense. ${ }^{31}$ Over the years attempts were made to formally reestablish military control over civilian authority. Therefore Chamorros were subject to contemporary political maneuvers on the part of the military to act as it deemed fit for national security without consent of the people of Guam (i.e. storage of warfare products including nuclear warheads, bombs, missiles, further land acquisition, and construction of storage facilities).

With regards to land the U.S. military has retained an overwhelming possession of Guam in spite of Chamorro resistance; moreover the combined ownership of the military, federal, and local government is $50 \%$ of the entire island. 32 With the downsizing of the military in the 1990s a huge proportion of Guam's land under military possession is in excess of military "need" yet remains off-limits to locals.

Compounding the situation, Guam's economy was absorbed into a new era of modern capitalism. In the heart of modern capitalism removal of restraints on private investment occurred, while Guam's economy experienced tremendous growth in the 1960s as a result of the rise of the tourist industry and other complimentary industries (i.e. construction, commerce, and imports). As Guam became positioned within the larger context of modern capitalist development in the Pacific, its economy was to experience fluctuating cycles of economic crisis and growth characteristic of capitalism in the years to come and hence to suffer the residual brunt of inconsistency, dramatic social, cultural and economic change, labor immigration, and exploitation. 
By the early 1970s tourism had expanded with high-rise hotels sprouting up on Tumon Beach (Guam's version of Waikiki). Japanese capitalist investments began to outweigh U.S. investments as Japan became the primary source of capital and tourists in Guam. Despite periods of economic growth Guam's economy continued to fluctuate through the years. For centuries Guam had been a thriving independent society that was transformed into a dependent welfare economy as a result of outside intrusions and dependent development. These conditions induced push-pull factors involving subsequent waves of Chamorro migration to the mainland to seek the American dream thus establishing permanent Chamorro communities especially in Southern California for years to come. ${ }^{33}$

By the late 1980s and early 1990s Guam's economy prospered while becoming increasingly dependent on Asian economies. An exodus of Filipino, Micronesian, Korean, Malaysian, and Chinese migrant laborers were recruited and began to pour in. These contemporary economic "developments" generated further exploitation of land, however moreso at the hands of capitalists as opposed to the military.

Once an independent self-sustaining society, Guam has become a dependent consumer society marked by urbanization. Inconsistent development of Guam's economy, compounded with urbanization and exploitation of land and labor have exacerbated infrastructural, social, and cultural problems. These negative residual effects of haphazard capitalist growth are prevalent today and observed in local concerns for identity, infrastructural strains, environmental crisis, and in-migration which have ignited revitalized Chamorro sentiments toward political self-determination.

\section{Political Self-Determination}

Subsequent generations began to recognize the neocolonialist relationship between the United States and Guam, and that in fact the return of the U.S. Liberation of Guam was not to save Chamorros but to save face and ensure U.S. military dominance in the Pacific. ${ }^{34}$ This consciousness served as an undercurrent of resistance that surfaced in the 1970s. Since the 1970s, there has been a proliferation of Chamorro resistance in response to the ongoing colonialist relationship 
between the U.S. and Guam. Chamorro self-determination and political status became the centerpiece of the political climate.

In the late 1970s Guam's political status efforts involved ongoing drafts of a Guam constitution. Sparked by a fierce Chamorro rights advocacy, a series of Chamorro rights organizations emerged, therefore signifying the proliferation of Chamorro nationalism.

In response to neocolonialist conditions, Chamorro activists and leaders pondered alternative strategies toward self-determination. Prompted by decolonization efforts among other U.S. colonies, a new strategy emerged on Guam that recognized the need to transform the existing neocolonialist relationship between Guam and the United States. In light of seemingly "successful" decolonization efforts of the Northern Mariana Islands and Puerto Rico, Guam's leaders pondered strategies toward decolonization and self-determination such as commonwealth, statehood, and free association. ${ }^{35}$ Through the years Guam's political status efforts have been an uphill struggle due to the lack of incentive on the part of the U.S. to decolonize a possession of which they desire to maintain control. Division among Chamorros regarding the most feasible alternative towards decolonization added to the difficulty of to constructing a solidified strategy-not to mention the division between World War II generation Chamorros who remained highly patriotic to the United States and subsequent generations of insurgent Chamorros.

Nonetheless Guam's status quest raged on. Following a handful of constitutional drafts, status commissions, and public opinion polls, Guam finally possessed a status goal by the late 1980s, that of a commonwealth, which was believed to increase the level of self-government while remaining under U.S. sovereignty and reaffirming U.S. citizenship,36 although diverse sentiments surrounding Guam's Draft Commonwealth Act revealed ambivalence and division.

Combined with Washington's reluctance to grant commonwealth status to Guam the resurgence of interethnic divisions concerning political status obscured the issue. At the intragroup level the Chamorro Movement appears to be splintering. For instance there is a discourse of resistance concerning the 
insufficient representation of indigenous Chamorro rights within the commonwealth proposal. At the inter-group level many non-Chamorros oppose Chamorro nationalism (which fueled the commonwealth movement) for its exclusionary connotations. Furthermore migrants (i.e. Filipinos, Micronesians) tend to oppose Commonwealth status on the grounds that it would shut off immigration by locating Guam outside the U.S. The Constitutional legitimacy of the Commonwealth proposal has also been questioned on the basis of "mutual consent," and "local control over immigration." 37 The Commonwealth quest has been difficult because of these diverse perspectives and interests.

On October 29, 1997, the Guam Commonwealth Act finally achieved a long awaited Congressional hearing, only the second hearing on the act within a ten year span. After pleas and testimonies from numerous Chamorro leaders and advocates, Deputy Secretary of Interior and President Clinton's representative for Guam Commonwealth negotiations, John Garamendi, indicated that the Administration was not willing to agree to three main areas of the act, mutual consent, immigration control, and Chamorro self-determination, core elements of the proposal. Therefore as Guam's non-voting delegate in Congress, Robert A. Underwood, states: "The most significant outcome of the hearing was the clarification of the executive branch's official position on the draft Act."38 The future of Guam's political status quest remains obscure and uncertain, but given the unclear course of affairs facing Guam, Joe T. San Agustin implies that despite the possibility of the Commonwealth quest not succeeding or at best being long and drawn out in the absence of a timetable, Chamorro commitment towards self-determination will persist, perhaps "even fuel the direction toward more radical forms." 39 Chamorro nationalism will continue to fuel indigenous political contestation. In fact current sentiments toward independence and statehood among activists and students who oppose Commonwealth have emerged in recent years.

\section{Historical and Contemporary Dynamics of Interethnic Antagonism inGuam}

Intergroup relations in Guam are evidently intertwined 
in a complex political, economic, and colonial history. In light of the outcome of the congressional hearing on Guam's Draft Commonwealth Act in 1997 immigration control and Chamorro self-determination remain central issues. These issues are driven by concerns for the maintenance of Chamorro culture, infrastructural strains, and the fear that Chamorros are becoming minorities in their own land. Indeed once making up an overwhelming majority of the population in Guam, Chamorros made up only $39 \%$ of the population in 1990.40 Given Guam's demographic shifts and increasing cultural diversity there is an unprecedented heterogeneity of interests with significant proportions of constituencies; therefore interethnic antagonism in Guam has reached new heights within an increasingly complex political, economic, cultural, and neocolonial context. In an attempt to capture this complexity I draw on diverse perspectives toward a general model to explain interethnic antagonism in a colonial territorial context. Figure 1 illustrates a conceptual model of the historical and contemporary dynamics of interethnic antagonism in Guam, which forms the basis of historical analysis.

\section{Classical and Neocolonialism}

The neocolonial relationship between Guam and the United States places the people of Guam in a precarious situation whereby intergroup conflict is inevitable. The current

FIGURE 1: Dynamics of Interethnic Antagonism in Guam

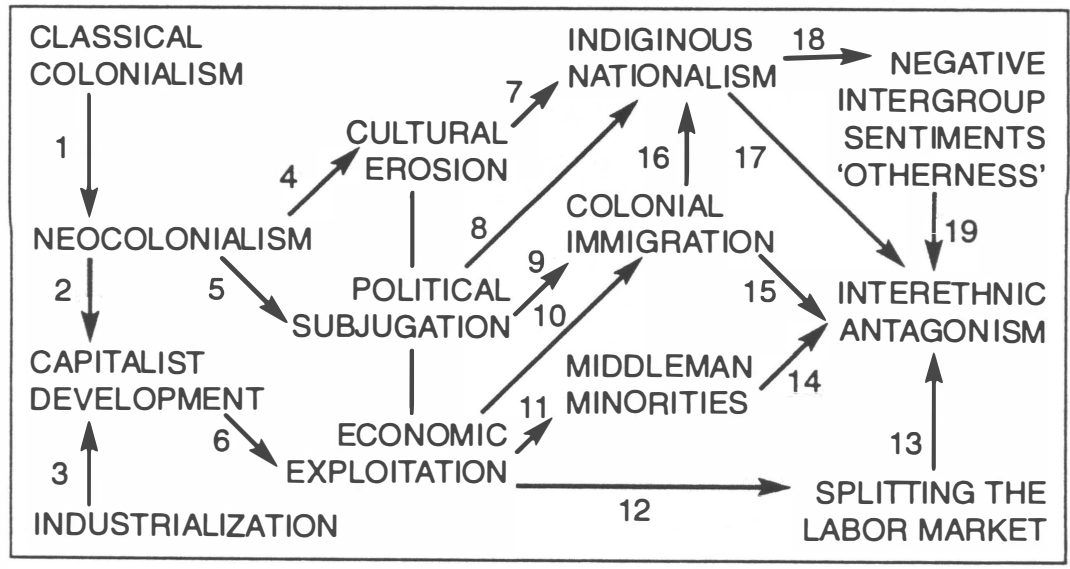


political relationship is rooted in a colonial history, in which conditions of classical colonialism remain intact under the guise of territorial relations.

Colonialism perspectives identify and isolate central conditions that typify colonialist processes and colonizer-colonized relationships. Classical or external colonialism refers to colonization of less "developed" societies by outside nation-states in the past. Drawing primarily on Robert Blauner's classic concept, there are five conditions of colonialism which facilitate conquest and domination: (1) forced entry, (2) physical and cultural genocide, (3) political subjugation, (4) exploitation, and (5) racism. ${ }^{41}$ Forced entry involves intrusion by a foreign nation. Forced entry can also refer to the forced absorption of a group into a colonial social system. Physical genocide refers to the blatant annihilation of a population through warfare and disease. Cultural genocide is the annihilation of indigenous culture and social structure. Political subjugation is the process by which colonized people are subject to the governance and policies of an invading nation. Exploitation during the classical colonialist period primarily involved exploitation of natural resources and labor for colonialist interests. Racism is both an outcome and justification of colonial processes and entails a multidimensional process involving individual, institutional, and ideological levels.

The colonial history of Guam from the Spanish conquest in the 1500s to the American occupation in the early 1900s displays colonial conditions on all counts. In turn the contemporary neocolonial situation in Guam is linked to this history (path one). Although many European and American colonies of the past achieved independence, many colonized territories continue to be economically and politically controlled by powerful nation-states. This ongoing subordirıation and dependence in the contemporary context is referred to as neocolonialism. Neocolonial theories highlight the ongoing process of colonialism whereby the conditions of classical colonialism are maintained in contemporary times to subordinate and control colonized populations within (internal colonialism) and out (external colonialism) of the nation-state. For instance the internal colony model has been extensively applied to minority communities on the U.S. mainland, but application to the U.S. ter- 
ritories is lacking. 42 This analysis specifically highlights three colonial conditions-cultural erosion, political subjugation, and economic exploitation-as foundations of interethnic antagonism (paths four, five, and six). The simultaneous entanglement of these colonial processes perpetuates a complex condition of interethnic antagonism vis-à-vis (path eight), middleman minority and split labor market processes (paths eleven and twelve), colonial immigration (path nine), and indigenous nationalism.

\section{Industrialization and Capitalist Development}

A key source of interethnic antagonism throughout the globe is embedded in the historical development of industrialization and capitalism. Intergroup relations in Guam are no exception. Therefore neo-Marxist theories are indeed applicable to economic processes in Guam. Although colonial theories recognize economic exploitation as a common condition of colonialism, neo-Marxist theories highlight the inherent role of labor exploitation under capitalism as a fundamental feature of social organization. 43 Likewise industrialization paralleled colonial expansion. As Lucie Cheng and Edna Bonacich reveal, modern capitalism is rooted in preindustrial imperialist expansion, which led to exploitation of land, immigrant labor and indigenous labor.44 Indeed industrialization of Guam is rooted in its colonial history. Without getting bogged down with the finer debates surrounding Marxist and postcolonial critiques, my point is to illustrate that common Marxist processes (i.e. driving down labor costs, exploitation of cheap labor, recruitment of immigrant and migrant labor) are crucial sources of labor immigration and ethnic conflict in Guam. In fact colonialism and capitalism are two sides of the same coin; therefore, economic exploitation is not merely a condition of colonialism as suggested by colonial theories but is essentially driven by capitalist development (path six) a key economic source of interethnic antagonism in Guam. Split labor market, middleman minority, and colonial immigration dynamics are therefore key features of interethnic antagonism in Guam. 


\section{Split Labor Market, Middleman Minorities, and Colonial Immigration}

The interconnections of capitalism and colonialism are rooted in divide and conquer colonial tactics. Split labor market theory succinctly captures this divide and conquer phenomenon in the context of capitalism. 45 Split labor market theory specifically highlights the segmentation of labor by capitalists to lower labor costs. By partitioning the labor market, potentially higher paid labor is undermined by introducing cheaper pockets of labor through labor immigration; therefore, competition and conflict are instigated between segments of labor to the support of capitalists and colonizers efforts to drive down labor costs and maintain control of the colonized. Labor segmentation often occurs across racial and ethnic lines, as certain minority groups historically occupy labor niches. In essence diverse racial and ethnic groups compete for meager resources, while the reality of their oppression is deflected away from the actual source. This often forms the economic basis of interethnic antagonism as racial and ethnic groups are pitted against one another.

Colonial immigration is, in turn, both a source of capitalist development and consequence of political subjugation (paths nine and ten). As noted labor immigration is a key characteristic of capitalism, whereby cheaper pockets of labor are continually sought to drive labor costs down. Capitalism also has an ideological effect by attracting immigrants who are in pursuit of the fruits of capitalism (path ten). Since Guam is "Where America's Day Begins," Guam has long been a popular destination for many immigrants in pursuit of the American Dream. Likewise since immigration policies are controlled by colonizers (path nine), the colonized often have no say regarding movement to and from their homeland. This is precisely the situation in Guam. 46

Although U.S. exploitation of Guam primarily involved land acquisition for military interests, thus diverging from the classic Marxist model, Marxist processes of economic exploitation of Chamorros and other minorities are nonetheless evident in Guam's history. For example at the brink of the American takeover of Guam in the late 1800s a significant number of Chamorro men were absorbed into early waves of capitalist 


\section{Ethnic Studies Review Volume 23}

labor migration to Hawaii. 47 Attempts were also made to use Chamorros as cheap labor to help establish a military fortress in Guam. By the late 1940s, the U.S. began incorporating splitlabor market tactics on Guam characteristic of Hawaii and the U.S. mainland. For instance due to labor shortages in Guam and to cut labor costs, American military and civilian contractors began recruiting large numbers of workers (especially from the Philippines) and constructing labor camps whose workers later became known as $\mathrm{H}-2$ workers. ${ }^{48}$ This labor system exploited both local and foreign labor and fostered interethnic antagonism especially between Chamorros and Filipinos that persists today. 49

Divide and conquer colonial split labor market tactics further take on a contemporary life of their own in the context of neocolonialism and advanced capitalism. Contemporary economic conditions are likewise a result of both military and capitalist exploitation. Although the military presence in Guam has contributed to the local economy in terms of employment and military production, the military continued to exploit labor in the 1950s and 1960s, especially foreign Filipino labor for military construction. The military has continued to exploit land and perpetuate economic stagnation. In spite of Chamorro political resistance to land subversion, the U.S. military has retained an overwhelming possession of Guam, which is a clear source of Chamorro animosity towards military personnel (largely Caucasians and African Americans). Moreover the combined ownership of the military, federal, and local government remains $50 \%$ of the entire island, much of which remains offlimits to locals as noted previously. Guam's strategic location for national defense continues to be the rationale. In short not much has changed for over forty years of American rule. Although Guam's economic development remained stagnant as a result of limitations imposed on the private sector by the military, dramatic changes sparked in the 1960s transformed Guam's economy in the following decades.

In the heart of modernization removal of restraints on private investment occurred. Guam's economy experienced tremendous growth in the 1960s as a result of the rise of the tourist industry and other complementary industries (i.e. construction, commerce, and imports). The stage was set for a 
new era of land and labor exploitation.

As Guam was absorbed into the larger world order of modern capitalist development, its economy experienced fluctuating cycles of economic crisis and prosperity characteristic of capitalism in general-and hence suffers the residual social problems associated with such inconsistency and dramatic socioeconomic change. As Laura Torres Souder states, Guam has become "a totally lopsided economy which is externally controlled." 50

Neo-Marxist perspectives are further applicable to Guam's economic (under)development, which is an additional dynamic of interethnic antagonism. In contrast to modernization perspectives neo-Marxist approaches suggest that this state of haphazard economic development is inherent to capitalist systems due to its short-term mentality and obsession with profitmaximization and labor exploitation.51 Modern capitalism has thus maintained its use of cheap labor rooted in preindustrial imperialist expansion which has led to exploitation of immigrant and indigenous labor. Splitting the labor market remains a major source of interethnic antagonism within advanced capitalism. During economic growth open-door policies commonly prevail to generate pull factors and promote labor in-migration. This has certainly been the case in Guam, especially in lieu of Chamorro resistance to being utilized as cheap labor. To complement the booming Guam economy in the 1960s there was a major shift in immigration policy and foreign labor:

...the "Aguino Ruling" (based on the Board of Immigration Appeals case) permitted certain categories of nonimmigrant alien workers admitted to Guam prior to December 1952, and still on the island owing to continuing contract employment, to remain as permanent U.S. residents under the 1917 Immigration Act.52

Over one thousand Filipino immigrants obtained permanent residence and eventually American citizenship. With the influx of their relatives Filipino migration poured in. This tremendous pocket of labor was exploited by the military and private industries for years. Then during the early 1960s the Immigration and Naturalization Service allowed Micronesian as well as Filipino workers to enter Guam for reconstruction pur- 
poses following the destruction of the island at the hands of Typhoon Karen in 1962. As Underwood states:

Karen was the first in a series of events and trends that facilitated the transformation of Guam into a multi-ethnic society.... After Karen, Guam's society became more complex and ethnically diverse. A multi-ethnic community grew within the context of an economic boom that featured tourism, foreign investment and enormous construction projects. 53

This context further increased the tide and exploitation of foreign workers while also introducing new pockets of exploitable labor from southern islands of Micronesia. Antiimmigrant sentiment among Chamorros swelled as ethnic competition for limited resources escalated, especially as the Filipino population grew to become the second largest ethnic group next to Chamorros. The impetus of this sentiment included labor competition, threats to indigenous culture, and lack of immigration control.

By the early 1970s, tourism had expanded with high-rise hotels sprouting up on Tumon Beach. As Japanese capitalist investments began to outweigh U.S. investments, Japan became the primary source of capital and tourists as previously noted. But the economy took a crisis turn in the mid 1970s, as tourism faltered. Characteristic of economic crisis (i.e. inflation, unemployment, bankruptcy, and debt) the number of welfare recipients increased while investments dwindled. For centuries Guam had been a thriving independent society that was transformed into a dependent welfare economy as a result of outside intrusions and dependent development, this time in the form of capitalist invasion. Thousands of Filipino workers repatriated to the Philippines.

Consistent with the fundamental haphazard feature of capitalist development en route, Guam's economy prospered in the 1980s sparked in part by rehabilitation efforts following Typhoon Pamela in the late 1970s. ${ }^{54}$ Tourism experienced growth once again with the building of an international airport. The airline industry reached new heights. Meanwhile more and more hotels were being constructed. Duty free shopping was also introduced. Private-sector employment and property value skyrocketed, while commercial banks and savings and 
Perez-Interethnic

loans corporations emerged. By the late 1980s and early 1990s Guam's economic boom reached new heights. With increased Japanese capital investment Guam's economic conditions became more dependent on Japan's economy versus the U.S. economy. As Souder also notes:

With the emergence of Japan as a world economic power, Guam is experiencing a "third" Japanese invasion vis-à-vis Japanese corporate investors who are buying land at inflationary prices and through their investments control the tourist industry. 55

As the Japanese community in Guam has developed through the years, anti-Japanese sentiment among Chamorros (perhaps traceable to the Japanese occupation) anecdotally seems to be exacerbated by Japanese capitalism. Robbery of and violence toward Japanese tourists is not unheard of.

In the midst of economic prosperity the need for workers increased once again, especially to perform construction and domestic service. In addition to Filipinos and Micronesians, Korean, Malaysian, and Chinese migrants were recruited and began to pour in. Exploitation became rampant as more pockets of cheap labor became accessible to capitalists. In 1986 pull factors attracting Micronesian migrants became especially profound when the U.S. established "free association" with the "new states" within the Trust Territory of the Pacific Islands (TTPI).56 Under free association the TTPI evolved into the Federated States of Micronesia and the Republics of the Marshalls and Palau. As U.S. nationals their citizens were granted freedom of travel to U.S. territories, thus opening the door to an exodus of thousands of Micronesians sparked by Guam's economic prosperity. Residents of Guam commonly refer to this situation as "Compact Impact," that is the negative impact (i.e. infrastructural strain, cultural erosion, population growth, crime rates) of the Compact agreement on Guam's infrastructure and culture. 57

Guam came to experience cultural lag resulting from this dramatic economic and population boom combined with insufficient infrastructure. Social problems that plagued former periods of economic upturn and influxes of migration resurfaced to more telling degrees. Electricity, roads, medical care, education, housing, and the criminal justice system remained defi- 


\section{Ethnic Studies Review Volume 23}

cient and increasingly strained. Anti-immigrant sentiment, interethnic antagonism, competition for meager resources, welfare dependency, and crime rates swelled. Capitalism has taken its toll on both migrants and locals, yet the true source of oppression continues to be clouded by interethnic animosity. Guam's communities seem to exhibit split-labor market characteristics similar to metropolitan cities on the U.S. mainland. Interethnic antagonism between Chamorros and Asians also seems to be enticed by middleman minority features of Guam, which are evident with an increasing tide of Asian migrants who bring entrepreneurial resources thus establishing mom-andpop businesses throughout the island. The rationale of middleman minority theory is that ethnic entrepreneurs occupy an intermediary niche thereby serving the interests of capitalists by purchasing products from and distributing goods for capitalists.58 Middleman minorities are both an exploited and exploitive class. They are exploited by capitalists based on their dependence on commodities produced on a larger scale by capitalists, while they exploit locals in the name of petite bourgeoisie profits. Since Guam has transformed into a consumer society dependent on imports thus exploited by exportoriented growth in exporting zones, middleman minority dynamics are additional sources of interethnic antagonism as locals (Chamorros and non-Chamorros) are forced to purchase imported products at inflationary prices.

In light of the complexity of Guam's colonial history and territorial status the immigration issue in Guam seems to diverge considerably from the anti-immigrant sentiment that escalated in the 1990s in California. In terms of the latter antiimmigrant feelings are rooted in Euro-American nativist hysteria and racist ideologies of immigrants themselves.59 Although some of this sentiment certainly exists on Guam, the primary issue at hand is inadequate infrastructure to absorb dramatic population growth and lack of immigration control on the part of the local people. As Underwood suggests:

It is merely the fact of numbers, the capacity of a society to absorb those numbers, and the desirability of a society being able to plan its future. If the numbers come from other sources, the concern over immigration would still be there. Put simply, a discussion over 
immigration cannot be dismissed as an expression of ethnic prejudice nor as an affront to the contributions of immigrants. These are not the issues at stake. The issue is, does a society have a right to control entry into its membership?60

The dramatic rise in the population and increase in social and economic needs of migrants has therefore tugged on Guam's already inadequate infrastructure. Guam has been transformed into a setting of urban decay. The negative residual effects of haphazard capitalist growth are prevalent today and observed in concerns regarding problems of the ecological environment, in-migration, welfare, crime, medical care, education, and self-determination. As Souder states;

The lack of control over who is allowed to reside on

Guam is a critical problem for several reasons.

Guam's finite resources cannot sustain a population

which is inflated unnaturally through in-migration.61

In sum contemporary capitalism introduced a more complex system of exploitation and dependency that moves beyond its imperialist roots. In addition to reliance on the U.S. military, Guam is economically dependent on tourism, imports and other related industries, while lacking the control to determine entry. Furthermore the interests of major political economic core powers within the New World Order converge on Guam (i.e. Japan and the United States). Economic consequences of neocolonialism are evidently manifested in the form of modern capitalism as explained by neo-Marxist perspectives. Once an independent self-sustaining society, Guam has become a dependent consumer society marked by urbanization. These are the precise concerns among Chamorros that have fueled counterhegemonic indigenous nationalist movements since the 1970s, which are additional sources of interethnic antagonism.

\section{Indigenous Nationalism, Inversion, and Otherness}

In light of the colonial conditions (i.e. cultural erosion, political subjugation, economic exploitation, colonial immigration) imposed on native people, indigenous nationalist movements are inevitable (paths seven, eight, and sixteen). As noted this is the nature of the landscape in Guam whereby Chamorros 


\section{Ethnic Studies Review Volume 23}

are particularly concerned with self-determination and becoming minorities on their own land. Rooted in an historical undercurrent of Chamorro resistance since contact, the 1970s marked a political and cultural movement of Chamorro nationalism. The "first island-wide grassroots political organization throughout the villages" was established in the early 1970s.62 In the late 1970s Chamorro rights advocacy escalated as political status and self-determination issues were brought to the fore. The neocolonial relationship between Guam and the United States was clearly recognized as a source of economic, political and cultural crises. Among the most active early indigenous Chamorro organizations to emerge was Na Para $\mathrm{Y}$ Pada Y Chamorros-"Stop slapping Chamorros."

In 1981 a subsequent nationalist grassroots organization, in turn, was formed, The Organization of People for Indigenous Rights (OPI-R). ${ }^{63}$ As an influential source of consciousness the OPI-R has likewise played a significant role in protecting Chamorro rights, promoting political and educational campaigns, and advocating Chamorro self-determination. OPI-R has been instrumental in facilitating the discourse on the "Chamorro inalienable right of self-determination."64

In the 1990s another grass-roots nationalist organization emerged, Chamoru Nation, which was formed on the basis of establishing a nation to promote the idea that indigenous people are self-sufficient. Seven fundamental elements of indigenous people in need of nurturing are identified that include language, culture, spiritual matters, water, air, land, and respectindigenous elements that are threatened by the lack of selfdetermination, Westernization, and fast rates of in-migration. Other nationalist organizations have likewise surfaced in recent years.

Nationalist indigenous movements are grounded in selfdetermination efforts to reclaim one's identity and destiny on cultural, political, and economic grounds. Such movements involve counter-colonial projects and have therefore resulted in ongoing resistance and gains among Chamorros in spite of seemingly dismal situations. Nonetheless indigenous nationalism is a source of interethnic antagonism in Guam.

Aside from political and economic sources of interethnic antagonism highlighted by colonial and neo-Marxist theories, 
the complexity of racial-ethnic and indigenous relations in Guam may be further captured within the sweeping canon of multidisciplinary scholarship identified broadly as cultural and postcolonial studies.65 The concepts of culture and power are critically redefined in the context of colonial structures and binarisms. The concept of otherness is a central outcome of colonial binarisms that perpetuate and justify distorted representations of colonized groups. Without getting lost in the finer terminology and discourse, I merely introduce the concept of otherness as relevant to my analysis of interethnic antagonism.

An underlying assumption of cultural and postcolonial studies is that colonialism continues to operate through structure and discourse maintained by the West in the context of culture and power. Otherness is a marker of cultural differences, whereby the "powers that be" monopolize ideological representations of the other. Binarisms are hence fundamental structures of discourse, that dichotomize identities into antithesis relations between opposing groups; therefore binarisms reify and signify boundaries of colonizer-colonized or self-other. 66

In terms of indigenous self-determination movements from a postcolonial standpoint, indigenous nationalism is interpreted as a mere inversion of this dichotomy (as opposed to a transformation) within the existing colonial structure, discourse, and perspective. In other words although nationalist projects contest colonial conditions in the name of decolonization, the fundamental colonial binarism of self versus other is paradoxically maintained. In fact subsequent binarisms are constructed and thus instigate intergroup cleavages. In a sense Chamorro nationalism does not transform meaningfully the existing colonial structure, but rather notions of otherness are constructed and imposed on non-Chamorros (many of which are colonized people as well). Diaz articulates the colonial history of conflict between Chamorro and Filipinos by locating their antagonistic relations within Guam's colonial history:

In fact, many "colonized" natives actually benefited and profited-and continue to benefit and profit-tremendously from the Euro-American colonization and neocolonization just as many suffer accordingly. This is precisely the story of the histori- 
cal development of national and countercolonial consciousness that historians such as Renato Constantino (1975) have written about.

A latent national Chamorro consciousness is surfacing in Guam, and Filipinos and other nonChamorros are very much a part of it, even if by opposition. The politics of culture and identity, and of national consciousness-in-formation, must be understood in relational and historical terms. 67

Combined with the fierce notions of indigenous self among Chamorros it is probable that their perceptions of others are equally fierce. Negative sentiments toward non-Chamorros (path eighteen) are enticed hence further perpetuating interethnic antagonism (paths seventeen and nineteen). The irony of divide and conquer colonial tactics is apparent in the fact that non-Chamorro minorities in Guam are perceived by Chamorros as "others" who are sources of the colonial problem rather than colonized brothers and sisters who mutually experience the negative consequences of colonization. This is the ideological dimension of divide and conquest processes.

\section{Concluding Remarks}

Guam is intertwined in a complex political history that has inevitably shaped a colonial landscape conducive to interethnic antagonism. On the one hand U.S. territories such as Guam seem to display similar dynamics of racial and ethnic relations as the U.S. mainland, but the more telling tale of places like Guam involves a fundamental divide and rule process that takes on a distinctive contemporary life in the context of being remote controlled within an overwhelming world order of capitalism and neocolonialism. I sought to capture some of this complexity by constructing an integrative multidisciplinary framework derived from diverse perspectives. The aim of this paper is to spark subsequent scholarship and empirical investigation of the historical entanglements associated with territorial racial, ethnic and indigenous relations.

\section{Notes}

1 I wish to extend my gratitude to Edna Bonacich for her support, insights and feedback. I also would like to express my appreciation 
for numerous discussions with Vicente M. Diaz, which sparked much of my thinking. However, any shortcomings are exclusively mine.

2 Edna Bonacich, "A Theory of Ethnic Antagonism: The Split Labor Market." American Sociological Review 37 (1972): 547-559.

3 Cobas, "Puerto Rican Reactions to Cuban Immigrants: Insights from Trading Minority Interpretations," Ethnic and Racial Studies 9(4) (1986): 529-536; Clive Moore and Patricia Mercer, "The Forgotten People: Australia's Immigrant Melanesians." Meanjin Quarterly 37(1) (1978): 98-108; Ronald Takaki, Strangers from a Different Shore: $\boldsymbol{A}$ History of Asian Americans. (New York: Penguin Books, 1989); Vicente M. Diaz, "Bye Bye Ms. American Pie: The Historical Relations Between Chamorros and Filipinos and the American Dream," ISLA: A Journal of Micronesian Studies 3(1) (Rainy Season 1995): 147-160. Diaz's work is virtually the only piece of scholarship on intergroup relations in Guam, which contributes a historical narrative of Chamorro-Filipino relations in the context of colonialism.

4 Diaz, "Bye Bye Ms. American Pie," 155.

5 Lawrence J. Cunningham, Ancient Chamorro Society (Honolulu, Hawaii: Bess Press Inc., 1992).

6 Robert R. Rogers, Destiny's Landfall: A History of Guam (Honolulu: University of Hawai'i Press, 1995); Robert A. Underwood, American Education and the Acculturation of the Chamorros of Guam (Ph.D. diss., University of Southern California, 1987).

7 Vicente M. Diaz, "Simply Chamorro: Tales of Demise and Survival in Guam." The Contemporary Pacific 6(1) (1994): 29-58.

8 United States Bureau of the Census, 1990 Census of Population and Housing: Social, Economic, and Housing Characteristics - Guam (CPH-6-G, 1990).

9 Although Guam is located in the Micronesian region of the Pacific Islands, "Micronesian" commonly refers to Pacific Islanders from the southern portion of the region, including Carolinians, Palauans, Chuukese, Kosraean, Marshallese, and Pohnpeian.

10 Don A. Farrel, The Pictorial History of Guam: The Sacrifice (San Jose, Tinian, Commonwealth of the Northern Mariana Islands: 
Ethnic Studies Review Volume 23

Micronesian Productions, 1991).

11 Rogers, Destiny's Landfall; Underwood, American Education.

12 Underwood, American Education; Katherine B. Aguon, "The Guam Dilemma: The Need for a Pacific Island Education Perspective." Hale'-ta, Hinasso': Tinige' Put Chamorro, Insights: The Chamorro Identity (Agana, Guam: Political Status Education Coordinating Commission, 1993); Laura Marie Torres Souder, Daughters of the Island: Contemporary Chamorro Women Organizers on Guam, Second Edition (NY: University Press of America, 1992); Laura Marie Torres Souder, "Psyche Under Siege: Uncle Sam, Look What You've Done to Us" in Uncle Sam in Micronesia: Social Benefits, Social Costs, eds. D.H. Rubinstein and V.L. Dames (Guam: Micronesian Area Research Center, University of Guam Press, 1991).

13 Underwood, American Education.

14 Rogers, Destiny's Landfall.

15 Rogers, Destiny's Landfal, 125.

16 Souder, Daughters of the Island, Souder, "Psyche Under Siege;" Underwood, American Education.

17 Rogers, Destiny's Landfal; Underwood, American Education.

18 Rogers, Destiny's Landfal; Michael F. Phillips "Land" in Kinalamten Pulitikat: Sinenten I Chamorro, Issue in Guam's Political Development: The Chamorro Perspective. (Agana, Guam: The Political Status Education Coordinating Commission, 1996).

19 Souder, Daughters of the Island, 31.

20 Underwood, American Education.

21 Rogers, Destiny's Landfall; Underwood, American Education.

22 Aguon, "The Guam Dilemma;" Underwood, American Education.

23 Souder, "Psyche Under Siege."

24 Ben Blaz, "Chamorros Yearn for Freedom." Liberation: Guam Remembers (Agana, Guam: Golden Salute Committee, 1994). 
25 With this emergent Chamorro sentiment, following World War II, the Chamorro population became split between patriotic Chamorros who continued to celebrate U.S. affiliation, and a minority of Chamorro civil rights advocates who remained discontent in spite of the American recapture of Guam from the Japanese. Nevertheless, the majority of Chamorros converged in their interests to become U.S. citizens.

26 Rogers, Destiny's Landfall.

27 Rogers, Destiny's Landfall.

28 Rogers, Destiny's Landfall; E. Robert Statham, Jr., "U.S. Citizenship Policy in the Territory of Guam: The Making of One Out of Many, or Many Out of One?" paper presented at the International Political Science Association XVII World Congress (Seoul, Korea, 1997).

29 Statham, "U.S. Citizenship."

30 Rogers, Destiny's Landfall.

31 Rogers, Destiny's Landfall; Underwood, American Education.

32 Rogers, Destiny's Landfall.

33 Faye Untalan Munoz, An Exploratory Study of Island Migration (Ph.D. diss., Ann Arbor, Michigan: University Microfilms International, 1979); Robert A. Underwood "Excursions into Inauthenticity: The Chamorros of Guam," Pacific Viewpoint 26(1) (1985): 160-184.

34 Souder, "Psyche Under Siege;" Vicente M. Diaz, "Deliberating Liberation Day: Identity, History, Memory and War in Guam." in Perilous Memories: The Asia Pacific Wars, eds. T. Fujitani, G.M. White and L. Yoneyama (Durham: Duke University Press, 1998); Robert A. Underwood, "Red, Whitewash and Blue: Painting Over the Chamorro Experience," Islander, 17 July, 1977.

35 Hope Alvarez Cristobal, "The Organization of People for Indigenous Rights: A Commitment Towards Self-Determination." in Hale'-ta. Hinasso': Tinige' Put Chamorro, Insights: The Chamorro Identity. (Agana, Guam: Political Status Education Coordinating Committee, 1993), 137-153; Rogers, Destiny's Landfall. 


\section{Ethnic Studies Review Volume 23}

36 Joe T. San Agustin, "The Quest for Commonwealth: A New Chapter in Guam's History." Kinalamten Pulitikat: Sinenten I Chamorro, Issues in Guam's Political Development: The Chamorro Perspective. (Agana, Guam: The Political Status Education Coordinating Commission, 1996), 119-124.

37 Statham, “U.S. Citizenship," 26.

38 Robert A. Underwood, "Commonwealth at a Crossroad," Asunton Kongresu: News from Congressman Robert A. Underwood (December 1997): 1. As one of Guam's former activist scholars, Robert Underwood's second career wave marks his position as Guam's non-voting delegate in Congress. His works cited in this paper prior to this 1997 publication reflect previous publications as an activist scholar. As Guam's representative in Congress, Underwood remains a crucial advocate of Guam's future.

39 San Agustin, “The Quest for Commonwealth," 12.

40 United States Bureau of the Census.

41 Robert Blauner, Racial Oppression in America (New York: Harper and Row, 1972).

42 Blauner, Racial Oppression; Mario Barrera, Race and Class in the Southwest (Notre Dame: University of Notre Dame Press, 1979); Christopher Bates Doob, Racism: An American Cauldron Third Edition. (New York: Addison Wesley Longman, Inc., 1999); Alfredo Mirande, The Chicano Experience: An Alternative Perspective (Notre Dame, Indiana: University of Notre Dame Press, 1985).

43 Bonacich, "A Theory of Ethnic Antagonism;" Lucie Cheng and Edna Bonacich, Labor Immigration Under Capitalism: Asian Workers in the United States (Berkeley, CA: University of California Press, 1984).

44 Cheng and Bonacich, Labor Immigration.

45 Bonacich, "A Theory of Ethnic Antagonism."

46 By comparison, the Commonwealth of the Northern Mariana Islands (also indigenous to Chamorros) and the U.S. have recently been in dispute over immigration control. As a Commonwealth, the local people in the Northern Marianas have controlled their immigration policy. As a result of the emerging garment industry in the 
Northern Marianas, the U.S. expresses a desire to impose its authority to control the Northern Mariana Islands' immigration in the name of protecting migrants from labor exploitation. However, the situation is paradoxical and highly charged in entanglements involving labor exploitation and paternalism.

47 Munoz, An Exploratory Study, Rogers, Destiny's Landfall.

48 Diaz, "Bye Bye Ms. American Pie;" Rogers, Destiny's Landfall; Underwood, American Education.

49 Diaz, "Bye Bye Ms. American Pie;" Souder, Daughters of the Island.

50 Souder, Daughters of the Island, 37.

51 Jeffrey Henderson and Manuel Castells, Global Restructuring and Territorial Development. (Newbury Park, CA: Sage, 1988); Joyce Kolko, Restructuring the World Economy. (New York: Pantheon, 1988).

52 Rogers, Destiny's Landfah, 236.

53 Underwood, American Education, 91.

54 Souder, Daughters of the Island.

55 Souder, Daughters of the Island, 36.

56 Rogers, Destiny's Landfall, 287.

57 Ronald Stade, Pacific Passages: World Culture and Local Politics in Guam. (Stockholm Studies in Social Anthropology, 1998).

58 Edna Bonacich, "A Theory of Middleman Minorities." American Sociological Review 38 (1973): 583-594.

59 Adalberto Aguirre, Jr., "Nativist Feelings and Mexican Immigrant Workers in California." Latino Studies Journal 6(3) (1995): 48-62.

60 Robert A. Underwood, "Immigration and Guam's Future," in Hale'ta Hinasso': Tinige' Put Chamorro, Insights: The Chamorro Identity. (Agana, Guam: Political Status Education Coordinating Committee, 1993), 135. 


\section{Ethnic Studies Review Volume 23}

61 Souder, Daughters of the Island, 34.

62 Rogers, Destiny's Landfall, 244

63 Cristobal, "The Organization of People."

64 Cristobal, "The Organization of People;" Souder, Daughters of the Island.

65 Bill Ashcroft, Gareth Griggiths and Helen Tiffin, The Postcolonial Studies Reader (New York: Routledge, 1995); Cary Nelson, Paula A. Treichler and Lawrence Grossberg, Cultural Studies. (New York and London: Routledge, 1992).

66 Edward Said, Orientalism (New York: Vintage Books, 1978). Said's seminal text, Orientalism, explores colonial binarisms through discourse analysis in the context of Western imperialist expansion and representations of the "Orient" as other.

67 Diaz, “Bye Bye Ms. American Pie," 157. 